\title{
Streptomyces qinglanensis sp. nov., isolated from mangrove sediment
}

\author{
Huo Hu, ${ }^{1,2}$ Hai-Peng Lin, ${ }^{1}$ Oingyi Xie, ${ }^{1}$ Lei Li, ${ }^{1}$ Xin-Qiang Xie ${ }^{1}$ \\ and Kui Hong ${ }^{1,2,3}$
}

\author{
Correspondence \\ Kui Hong \\ k1022@163.net
}

\author{
${ }^{1}$ Institute of Tropical Bioscience and Biotechnology, Chinese Academy of Tropical Agriculture \\ Sciences, Haikou 571101, PR China \\ ${ }^{2}$ College of Life Science and Technology, Huazhong Agricultural University, Wuhan 430070, \\ PR China \\ ${ }^{3}$ Key Laboratory of Combinatorial Biosynthesis and Drug Discovery (Wuhan University), Ministry of \\ Education, and Wuhan University School of Pharmaceutical Sciences, Wuhan 430071, PR China
}

The genus Streptomyces was proposed by Waksman \& Henrici (1943) and, at the time of writing, encompasses over 500 recognized species (Euzéby, 2010; http://www. bacterio.cict.fr/s/streptomycesa.html). Species of the genus Streptomyces are well known as a rich source of antibiotics and bioactive molecules and they are thus considered to be a rich biotechnological resource (Chun et al., 1997; Labeda et al., 1997; Iwai \& Takahashi, 1992). The ability of streptomycetes to produce antibiotics and other industrially significant secondary metabolites remains unsurpassed (Sanglier et al., 1996; Ōmura et al., 2001; Watve et al., 2001; Bentley et al., 2002; Ikeda et al., 2003; Ward \& Goodfellow, 2004; Bérdy, 2005). One environment from which novel species of streptomycetes have been isolated is mangroves (Xu et al., 2009; Xiao et al., 2009; Sui et al., 2011).

A soil sample from Qinglan Harbour mangrove was pretreated by the dispersion and differential centrifugation

The GenBank/EMBL/DDBJ accession number for the 16S rRNA gene sequence of strain $172205^{\top}$ is $\mathrm{HQ660227.}$

One supplementary table and a supplementary figure are available with the online version of this paper. technique (Hopkins et al., 1991) and strain $172205^{\mathrm{T}}$ was isolated on Gauze No. 1 medium (Gauze et al., 1983). Strong activity against the human immortalized myelogenous leukaemia cell line K562 was discovered from crude extracts of strain $172205^{\mathrm{T}}$ fermentation broth (Hong et al., 2009). The purified strain was maintained on yeast extract-malt extract agar (International Streptomyces Project medium no. 2, ISP 2) (Shirling \& Gottlieb, 1966) slopes at $4{ }^{\circ} \mathrm{C}$ for shortterm preservation and as glycerol suspensions $(20 \%, \mathrm{v} / \mathrm{v})$ at $-80{ }^{\circ} \mathrm{C}$ for long-term preservation (Wellington \& Williams, 1978).

Morphology was observed by light microscopy (80i; Nikon) and scanning electron microscopy (S-3000N; Hitachi) of ISP 3 agar cultures incubated at $28{ }^{\circ} \mathrm{C}$ for 15 days. Cultural characteristics were determined after 2 weeks at $28{ }^{\circ} \mathrm{C}$ according to the methods proposed by Shirling \& Gottlieb (1966). Colony colour was determined by reference to ISCC-NBS colour charts (Kelly, 1964). The physiological and biochemical characteristics of strain $172205^{\mathrm{T}}$ and its phylogenetically closest neighbours were tested under the same conditions, by using the well-established procedures of Williams et al. (1983) and Kämpfer et al. (1991). The 
utilization of sole carbon and nitrogen sources was analysed according to the methods described by Shirling \& Gottlieb (1966). Growth at 4,10,15, 20, 28, 37, 40, 45 and $55^{\circ} \mathrm{C}$ was tested on modified Bennett's agar (Jones, 1949) plates incubated for 7-14 days. $\mathrm{NaCl}$ tolerance $(0,1,3,5,7,9,10$, 15 and $25 \%, \mathrm{w} / \mathrm{v})$ and the $\mathrm{pH}$ range for growth $(\mathrm{pH} \mathrm{4,5,7}$ 9, 10 and 11) were determined in liquid modified Bennett's medium $(1.0 \mathrm{~g}$ yeast extract, $0.8 \mathrm{~g}$ beef extract, $2.0 \mathrm{~g}$ Casitone, $10.0 \mathrm{~g}$ glycerol, $18.0 \mathrm{~g}$ agar, $\mathrm{pH}$ 7.3) incubated at $28{ }^{\circ} \mathrm{C}$ for $7-14$ days.

Biomass for chemical and molecular systematic studies was obtained after incubation at $28{ }^{\circ} \mathrm{C}$ for 3-6 days in shaken flasks (about 180 r.p.m.) of trypticase soy broth (TSB). Amino acids and sugars in whole-cell hydrolysates were analysed according to the procedures of Lechevalier \& Lechevalier (1980) by TLC. Cellular fatty acids were extracted according to the method of Sasser (1990) and the composition was determined by GC (Oliver \& Colwell, 1973). Menaquinones were extracted from freeze-dried biomass, purified according to Minnikin et al. (1984) and analysed by HPLC with an ODS-BP $\mathrm{C}_{18}$ column $(4.6 \times$ $250 \mathrm{~mm}$ ). Phospholipid analysis was carried out by TLC by using the technique described by Minnikin et al. (1984).

Preparation of genomic DNA, PCR amplification and sequencing of the $16 \mathrm{~S}$ rRNA gene were carried out by using the procedures described by Goodfellow et al. (2007). The $16 \mathrm{~S}$ rRNA gene sequence of strain $172205^{\mathrm{T}}$ was multiply aligned with representative sequences of related streptomycetes obtained from the GenBank/EMBL/DDBJ databases by using CLUSTAL $\mathrm{x}$ software. The alignment was manually verified and adjusted prior to the reconstruction of a phylogenetic tree. The unrooted phylogenetic tree was generated via the neighbour-joining (Saitou \& Nei, 1987) and maximum-parsimony (Fitch, 1971) tree-making algorithms in MEGA, version 4.0 (Tamura et al., 2007); evolutionary distances for the neighbour-joining algorithm were calculated with the Kimura two-parameter model (Kimura, 1980). The topologies of the resultant trees were evaluated in a bootstrap analysis (Felsenstein, 1985) of 1000 replicates. Levels of pairwise 16S rRNA gene sequence similarity between the closest strains were determined by using the EzTaxon server (http://www.Eztaxon.org) (Chun et al., 2007). All positions containing gaps and missing data were eliminated from the dataset (complete deletion option).

Chromosomal DNA was extracted as described by Pospiech \& Neumann (1995). The DNA G + C content of strain $172205^{\mathrm{T}}$ was determined by the HPLC method (Mesbah et al., 1989). Levels of DNA-DNA relatedness were measured on nylon membranes according to the method described by Wang et al. (2011).

Morphological features were observed on ISP 1-7 (Shirling \& Gottlieb, 1966), modified Bennett's agar (Jones, 1949), Czapek's agar (Wiese et al., 2008) and nutrient agar. Results of the physiological characterization are given in the species

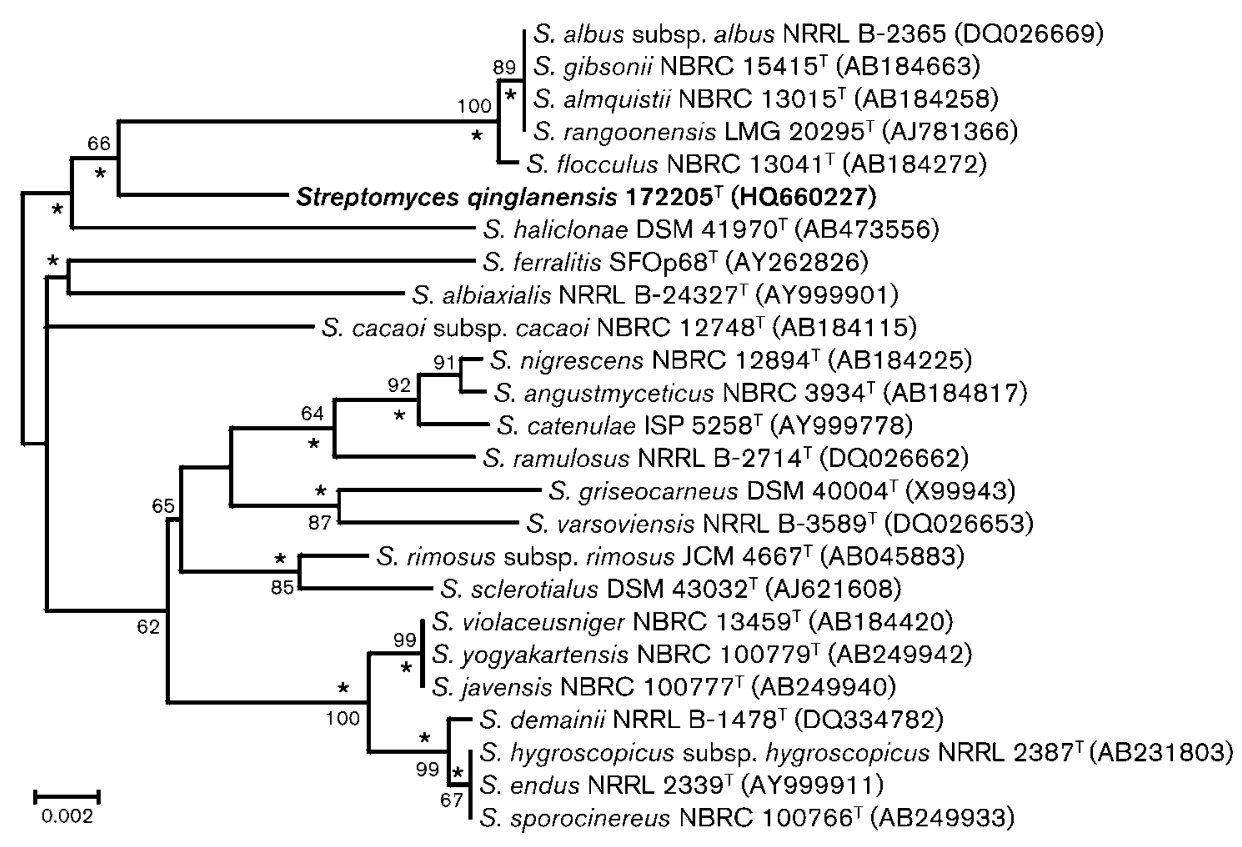

Fig. 1. Neighbour-joining phylogenetic tree, based on nearly complete $16 \mathrm{~S}$ rRNA gene sequences (1455 nt), showing the relationships between strain $172205^{\top}$ and related representative species of the genus Streptomyces. Numbers at branch points indicate bootstrap percentages (based on 1000 replications); only values $>50 \%$ are shown. Asterisks indicate branches of the tree that were also recovered by using the maximum-parsimony tree-making algorithm. Bar, 0.002 substitutions per nucleotide position. 
Table 1. Physiological and biochemical properties of strain $172205^{\top}$ that differentiate it from its closest phylogenetic neighbours in the genus Streptomyces

Strains: $1,172205^{\mathrm{T}}$; 2, S. flocculus NBRC $13041^{\mathrm{T}}$; 3, S. ferralitis SFOp $68^{\mathrm{T}}$; 4, S. haliclonae DSM $41970^{\mathrm{T}}$. ++ , Strongly positive; + , positive; \pm , weakly positive; - , negative. The data presented are from this study unless indicated otherwise.

\begin{tabular}{|c|c|c|c|c|}
\hline Characteristic & 1 & 2 & 3 & 4 \\
\hline \multicolumn{5}{|l|}{ Morphology } \\
\hline Colour of colony on ISP 1 & White & White & None & White \\
\hline Reverse side of colony on ISP 1 & Green-beige & Sulfur yellow & Beige & Beige \\
\hline Growth on ISP 1 & Good & Good & Fair & Fair \\
\hline Colour of colony on Czapek's agar & White & None & None & White \\
\hline Reverse side of colony on Czapek's agar & Oyster white & Ivory & Beige & Dull white \\
\hline Growth on Czapek's agar & Fair & Sparse & Sparse & Fair \\
\hline \multicolumn{5}{|l|}{ Growth at/with: } \\
\hline $40{ }^{\circ} \mathrm{C}$ & - & + & + & - \\
\hline $45^{\circ} \mathrm{C}$ & - & + & - & - \\
\hline $7 \%(\mathrm{w} / \mathrm{v}) \mathrm{NaCl}$ & + & + & - & $-{ }^{*}$ \\
\hline $9,10 \%(\mathrm{w} / \mathrm{v}) \mathrm{NaCl}$ & + & + & - & - \\
\hline pH 5 & - & + & + & + \\
\hline \multicolumn{5}{|l|}{ Carbon utilization } \\
\hline Raffinose & \pm & + & - & + \\
\hline L-Arabinose & ++ & + & - & - \\
\hline Sodium citrate & - & + & - & - \\
\hline Cellobiose & ++ & ++ & - & + \\
\hline D- $(+)$-Galactose & ++ & ++ & $-\dagger$ & ++ \\
\hline Melibiose & \pm & - & - & ++ \\
\hline L- $(+)$-Rhamnose & - & - & - & $+^{*}$ \\
\hline \multicolumn{5}{|l|}{ Nitrogen utilization } \\
\hline L-Valine & - & + & + & - \\
\hline L-Histidine & - & + & + & - \\
\hline D-Arginine & + & + & - & + \\
\hline L-Glutamine & + & + & - & + \\
\hline L-Methionine & - & - & + & - \\
\hline Hydroxy-L-proline & - & - & + & - \\
\hline L-Phenylalanine & - & - & + & - \\
\hline L-Proline & - & + & + & - \\
\hline L-Ornithine & - & - & + & - \\
\hline L-Asparagine & - & + & + & + \\
\hline Glycine & - & + & + & - \\
\hline L-Serine & - & + & + & + \\
\hline \multicolumn{5}{|l|}{ Degradation of: } \\
\hline CM-cellulose & + & - & \pm & - \\
\hline Starch & + & - & - & $+^{\star}$ \\
\hline Gelatin & - & + & - & + \\
\hline Urea & + & + & $-\dagger$ & $+^{*}$ \\
\hline Aesculin & - & + & - & + \\
\hline Tweens $20,40,80$ & + & + & - & + \\
\hline DNA G $+\mathrm{C}$ content $(\mathrm{mol} \%)$ & 70.33 & 71 & 73.8 & $72 \ddagger$ \\
\hline Menaquinones & MK-9 $\left(\mathrm{H}_{6}\right)$, MK-9 $\left(\mathrm{H}_{8}\right)$ & MK-9 $\left(\mathrm{H}_{6}\right)$, MK-9 $\left(\mathrm{H}_{8}\right)$ & MK-9 $\left(\mathrm{H}_{6}\right)$, MK-9 $\left(\mathrm{H}_{8}\right)$ & MK-9 $\left(\mathrm{H}_{6}\right)$, MK-9 $\left(\mathrm{H}_{8}\right)$ \\
\hline Phospholipids $§$ & PE, ALs, PLs & PE, DPG, ALs, PLs & PE, DPG, PLs & PE, DPG, ALs, 5 PLs \\
\hline
\end{tabular}

${ }^{\star}$ Data from Khan et al. (2010) are contradictory to the result obtained in this study.

$\dagger$ Data from Saintpierre-Bonaccio et al. (2004) are contradictory to the result obtained in this study.

$\ddagger$ Data from Khan et al. (2010).

§AL, unknown aminolipid; DPG, diphosphatidylglycerol; PE, phosphatidylethanolamine; PL, unknown phospholipid. 
description below. The almost-complete 16S rRNA gene sequence of strain $172205^{\mathrm{T}}$ (1487 nt) was obtained and compared with those sequences available on the EzTaxon server (Chun et al., 2007). Strain $172205^{\mathrm{T}}$ showed highest $16 \mathrm{~S}$ rRNA gene sequence similarity of $98.29 \%$ with Streptomyces flocculus NBRC $13041^{\mathrm{T}}$, corresponding to $25 \mathrm{nt}$ differences at 1463 sites. A neighbour-joining tree based on 16S rRNA gene sequences showing the position of strain $172205^{\mathrm{T}}$ and its closest phylogenetic relatives is presented in Fig. 1. Strain $172205^{\mathrm{T}}$ formed an independent subclade, supported by maximum-parsimony analysis, but was associated with $S$. flocculus NBRC $13041^{\mathrm{T}}$ (98.29\% $16 \mathrm{~S}$ rRNA gene sequence similarity), Streptomyces ferralitis $\mathrm{SFOp} 68^{\mathrm{T}}(98.14 \%)$ and Streptomyces haliclonae DSM $41970^{\mathrm{T}}(98.08 \%)$. Levels of DNA-DNA relatedness between strain $172205^{\mathrm{T}}$ and $S$. flocculus NBRC $13041^{\mathrm{T}}$, S. ferralitis SFOp $68^{\mathrm{T}}$ and S. haliclonae DSM $41970^{\mathrm{T}}$ were $50.28 \pm 4,49.15 \pm 11$ and $37.56 \pm 11 \%$ (mean \pm SD of 6 determinations), respectively, values below the $70 \%$ threshold proposed by Wayne et al. (1987) for distinguishing genomic species.

The quinone system supported the affiliation of strain $172205^{\mathrm{T}}$ to the genus Streptomyces, where the major menaquinones were MK-9 $\left(\mathrm{H}_{6}\right)$ and MK-9 $\left(\mathrm{H}_{8}\right)$ (Collins et al., 1977; Minnikin et al., 1984). The diagnostic phospholipid of strain $172205^{\mathrm{T}}$ was phosphatidylethanolamine. The main fatty acids of strain $172205^{\mathrm{T}}$ were iso- $\mathrm{C}_{12: 0}$ $(6.68 \%)$, iso- $\mathrm{C}_{14: 0}(9.35 \%)$, iso- $\mathrm{C}_{15: 0}(10.31 \%)$, anteiso$\mathrm{C}_{15: 0}(35.19 \%), \mathrm{C}_{14: 0} 3-\mathrm{OH}(8.14 \%)$, iso- $\mathrm{C}_{16: 0}(20.24 \%)$ and anteiso- $\mathrm{C}_{17: 0}(10.05 \%)$. This profile differs from those of its three closest phylogenetic relatives (see Supplementary Table S1 available in IJSEM Online).

Differences in various characteristics show that strain $172205^{\mathrm{T}}$ is phenotypically distinct from its closest phylogenetic relatives, S. flocculus NBRC $13041^{\mathrm{T}}$, S. ferralitis SFOp $68^{\mathrm{T}}$ and S. haliclonae DSM $41970^{\mathrm{T}}$ (Table 1). Therefore, it is evident that strain $172205^{\mathrm{T}}$ represents a novel species of the genus Streptomyces, for which the name Streptomyces qinglanensis sp. nov. is proposed.

\section{Description of Streptomyces qinglanensis sp. nov.}

Streptomyces qinglanensis (qing.lan.en'sis. N.L. masc. adj. qinglanensis pertaining to Qinglan Harbour, Wenchang, Hainan, from where the type strain was isolated).

Good growth occurs on ISP 1, 2, 3, 6 and 7, modified Bennett's agar, nutrient agar and Czapek's agar, while weak growth is observed on ISP 4 and 5 agar media. White aerial mycelium is formed on ISP 1, 2, 3, 4 and 6, modified Bennett's agar, Czapek's agar and nutrient agar. No diffusible pigment or melanin is detected on any of the tested media. After 15 days of growth on ISP 3 agar at $28{ }^{\circ} \mathrm{C}$, both aerial and vegetative hyphae are abundant, well developed and show typical characteristics of the genus Streptomyces. Spore chains are long and Rectiflexibiles in nature, consisting of about 16 spores. Spores are elliptical or short rod-shaped $(0.3-0.7 \times 0.5-1.0 \mu \mathrm{m})$. The spore surfaces are smooth (see Supplementary Fig. S1). Positive in tests for CM-cellulose degradation, catalase production, starch hydrolysis, urease production, and degradation of Tweens 20, 40 and 80; negative for gelatin liquefaction, aesculin degradation and nitrate reduction (Table 1). Growth occurs at $\mathrm{pH} 7.0-10.0$ (optimum, $\mathrm{pH} 7.0$ ), at $15-37{ }^{\circ} \mathrm{C}$ (optimum, $28{ }^{\circ} \mathrm{C}$ ) and with $0-25 \%(\mathrm{w} / \mathrm{v}) \mathrm{NaCl}$ [optimum, $1-3 \%(\mathrm{w} / \mathrm{v})$ $\mathrm{NaCl}$. Utilizes raffinose (weakly), inositol, L-arabinose, sucrose, D-glucose, D-mannitol, D-arabinose, cellobiose, D$(+)$-galactose, melibiose (weakly), trehalose, $\mathrm{D}-(+)$-xylose, D-fructose and $\mathrm{D}-(+)$-mannose as sole carbon and energy sources, but not sodium citrate, D-sorbitol or L- $(+)$ rhamnose. Metabolizes L-alanine, D-arginine and L-glutamine as sole nitrogen sources, but not L-valine, L-cysteine, L-histidine, L-methionine, hydroxy-L-proline, L-phenylalanine, L-proline, L-ornithine, L-asparagine, glycine or Lserine. Possesses both LL-diaminopimelic acid and mesodiaminopimelic acid and whole-cell hydrolysates contain ribose, galactose and glucose. The polar lipid profile comprises phosphatidylethanolamine, an unknown aminolipid and five unknown phospholipids. Major menaquinones are MK-9 $\left(\mathrm{H}_{6}\right)$ and MK- $9\left(\mathrm{H}_{8}\right)$. The major fatty acids are iso- $\mathrm{C}_{15: 0}$, anteiso- $\mathrm{C}_{15: 0}$, iso- $\mathrm{C}_{16: 0}$ and anteiso- $\mathrm{C}_{17: 0}$. The $\mathrm{G}+\mathrm{C}$ content of the genomic DNA of the type strain is $70.33 \mathrm{~mol} \%$.

The type strain, $172205^{\mathrm{T}}\left(=\mathrm{CGMCC} 4.6825^{\mathrm{T}}=\mathrm{DSM}\right.$ $\left.42035^{\mathrm{T}}\right)$, which exhibits cytotoxic activity against human immortalized myelogenous leukaemia cell line K562, was isolated from a composite mangrove soil sample collected in Qinglan Harbour, Wenchang, Hainan Province, China.

\section{Acknowledgements}

This research was supported by grants from the National High Technology Research and Development Program of China (863 Program) (no. 2007AA09Z415) and the National Natural Science Foundation of China (no. U0633008).

\section{References}

Bentley, S. D., Chater, K. F., Cerdeño-Tárraga, A. M., Challis, G. L., Thomson, N. R., James, K. D., Harris, D. E., Quail, M. A., Kieser, H. \& other authors (2002). Complete genome sequence of the model actinomycete Streptomyces coelicolor A3(2). Nature 417, 141-147.

Bérdy, J. (2005). Bioactive microbial metabolites. J Antibiot (Tokyo) 58, $1-26$.

Chun, J., Youn, H. D., Yim, Y.-I., Lee, H., Kim, M. Y., Hah, Y. C. \& Kang, S.-O. (1997). Streptomyces seoulensis sp. nov. Int J Syst Bacteriol 47, 492-498.

Chun, J., Lee, J. H., Jung, Y., Kim, M., Kim, S., Kim, B. K. \& Lim, Y. W. (2007). EzTaxon: a web-based tool for the identification of prokaryotes based on $16 \mathrm{~S}$ ribosomal RNA gene sequences. Int J Syst Evol Microbiol 57, 2259-2261.

Collins, M. D., Pirouz, T., Goodfellow, M. \& Minnikin, D. E. (1977). Distribution of menaquinones in actinomycetes and corynebacteria. J Gen Microbiol 100, 221-230.

Euzéby, J. (2010). List of prokaryotic names with standing in nomenclature. http://www.bacterio.cict.fr/s/streptomycesa.html 
Felsenstein, J. (1985). Confidence limits on phylogenies: an approach using the bootstrap. Evolution 39, 783-791.

Fitch, W. M. (1971). Toward defining the course of evolution: minimum change for a specific tree topology. Syst Zool 20, 406-416.

Gauze, G. F., Preobrazhenskaya, T. P., Sveshnikova, M. A., Terekhova, L. P. \& Maksimova, T. S. (1983). Opredelitel' aktinomitsetov (Manual of Actinomycetes). Moscow: Nauka.

Goodfellow, M., Kumar, Y., Labeda, D. P. \& Sembiring, L. (2007). The Streptomyces violaceusniger clade: a home for streptomycetes with rugose ornamented spores. Antonie van Leeuwenhoek 92, 173-199.

Hong, K., Gao, A. H., Xie, Q. Y., Gao, H., Zhuang, L., Lin, H. P., Yu, H. P., Li, J., Yao, X. S. \& other authors (2009). Actinomycetes for marine drug discovery isolated from mangrove soils and plants in China. Mar Drugs 7, 24-44.

Hopkins, D. W., Macnaughton, S. J. \& O'Donnell, A. G. (1991). A dispersion and differential centrifugation technique for representatively sampling microorganisms from soil. Soil Biol Biochem 23, 217225.

Ikeda, H., Ishikawa, J., Hanamoto, A., Shinose, M., Kikuchi, H., Shiba, T., Sakaki, Y., Hattori, M. \& Ōmura, S. (2003). Complete genome sequence and comparative analysis of the industrial microorganism Streptomyces avermitilis. Nat Biotechnol 21, 526-531.

Iwai, H. \& Takahashi, Y. (1992). Selection of microbial sources of bioactive compounds. In The Search for Bioactive Compounds from Microorganisms, pp. 281-302. Edited by S. Ōmura. New York: Springer.

Jones, K. L. (1949). Fresh isolates of actinomycetes in which the presence of sporogenous aerial mycelia is a fluctuating characteristic. J Bacteriol 57, 141-145.

Kämpfer, P., Kroppenstedt, R. M. \& Dott, W. (1991). A numerical classification of the genera Streptomyces and Streptoverticillium using miniaturized physiological tests. J Gen Microbiol 137, 1831-1891.

Kelly, K. L. (1964). Inter-Society Color Council - National Bureau of Standards Color Name Charts Illustrated with Centroid Colors. Washington, DC: US Government Printing Office.

Khan, T. K., Tamura, T., Takagi, M. \& Shin-ya, K. (2010). Streptomyces tateyamensis sp. nov., Streptomyces marinus sp. nov. and Streptomyces haliclonae sp. nov., isolated from the marine sponge Haliclona sp. Int $J$ Syst Evol Microbiol 60, 2775-2779.

Kimura, M. (1980). A simple method for estimating evolutionary rates of base substitutions through comparative studies of nucleotide sequences. J Mol Evol 16, 111-120.

Labeda, D. P., Lechevalier, M. P. \& Testa, R. T. (1997). Streptomyces stramineus sp. nov., a new species of the verticillate streptomycetes. Int J Syst Bacteriol 47, 747-753.

Lechevalier, M. P. \& Lechevalier, H. A. (1980). The chemotaxonomy of actinomycetes. In Actinomycete Taxonomy, pp. 22-291. Edited by A. Dietz \& D. W. Thayer. Arlington, VA: Society for Industrial Microbiology.

Mesbah, M., Premachandran, U. \& Whitman, W. B. (1989). Precise measurement of the $\mathrm{G}+\mathrm{C}$ content of deoxyribonucleic acid by highperformance liquid chromatography. Int J Syst Bacteriol 39, 159-167.

Minnikin, D. E., O’Donnell, A. G., Goodfellow, M., Alderson, G., Athalye, M., Schaal, A. \& Parlett, J. K. (1984). An integrated procedure for the extraction of bacterial isoprenoid quinones and polar lipids. J Microbiol Methods 2, 233-241.

Oliver, J. D. \& Colwell, R. R. (1973). Extractable lipids of gramnegative marine bacteria: fatty-acid composition. Int J Syst Bacteriol 23, 442-458.

Ōmura, S., Ikeda, H., Ishikawa, J., Hanamoto, A., Takahashi, C., Shinose, M., Takahashi, Y., Horikawa, H., Nakazawa, H. \& other authors (2001). Genome sequence of an industrial microorganism Streptomyces avermitilis: deducing the ability of producing secondary metabolites. Proc Natl Acad Sci U S A 98, 12215-12220.

Pospiech, A. \& Neumann, B. (1995). A versatile quick-prep of genomic DNA from gram-positive bacteria. Trends Genet 11, 217218.

Saintpierre-Bonaccio, D., Amir, H., Pineau, R., Lemriss, S. \& Goodfellow, M. (2004). Streptomyces ferralitis sp. nov., a novel streptomycete isolated from a New-Caledonian ultramafic soil. Int $J$ Syst Evol Microbiol 54, 2061-2065.

Saitou, N. \& Nei, M. (1987). The neighbor-joining method: a new method for reconstructing phylogenetic trees. Mol Biol Evol 4, 406425.

Sanglier, J. J., Haag, H., Huck, T. A. \& Fehr, T. (1996). Review of actinomycetes compounds 1990-1995. Expert Opin Investig Drugs 5, 207-223.

Sasser, M. (1990). Identification of bacteria by gas chromatography of cellular fatty acids, Technical Note 101. Newark, DE: Microbial ID.

Shirling, E. B. \& Gottlieb, D. (1966). Methods for characterization of Streptomyces species. Int J Syst Bacteriol 16, 313-340.

Sui, J. L., Xu, X. X., Qu, Z., Lin, H. P., Ruan, J. S. \& Hong, K. (2011). Streptomyces sanyensis sp. nov., isolated from mangrove sediment. Int J Syst Evol Microbiol 61, 1632-1637.

Tamura, K., Dudley, J., Nei, M. \& Kumar, S. (2007). MEGA4, molecular evolutionary genetics analysis (MEGA) software version 4.0. Mol Biol Evol 24, 1596-1599.

Waksman, S. A. \& Henrici, A. T. (1943). The nomenclature and classification of the actinomycetes. J Bacteriol 46, 337-341.

Wang, C., Xu, X. X., Qu, Z., Wang, H. L., Lin, H. P., Xie, Q. Y., Ruan, J. S. \& Hong, K. (2011). Micromonospora rhizosphaerae sp. nov., isolated from mangrove rhizosphere soil. Int J Syst Evol Microbiol 61, 320-324.

Ward, A. C. \& Goodfellow, M. (2004). Phylogeny and functionality: taxonomy as a roadmap to genes. In Microbial Diversity and Bioprospecting, pp. 288-313. Edited by A. T. Bull. Washington, DC: American Society for Microbiology.

Watve, M. G., Tickoo, R., Jog, M. M. \& Bhole, B. D. (2001). How many antibiotics are produced by the genus Streptomyces? Arch Microbiol 176, 386-390.

Wayne, L. G., Brenner, D. J., Colwell, R. R., Grimont, P. A. D., Kandler, O., Krichevsky, M. I., Moore, L. H., Moore, W. E. C., Murray, R. G. E. \& other authors (1987). International Committee on Systematic Bacteriology. Report of the ad hoc committee on reconciliation of approaches to bacterial systematics. Int J Syst Bacteriol 37, 463-464.

Wellington, E. M. H. \& Williams, S. T. (1978). Preservation of actinomycete inoculum in frozen glycerol. Microbiol Lett 6, 151-157.

Wiese, J., Jiang, Y., Tang, S. K., Thiel, V., Schmaljohann, R., Xu, L. H., Jiang, C. L. \& Imhoff, J. F. (2008). A new member of the family Micromonosporaceae, Planosporangium flavigriseum gen. nov., sp. nov. Int J Syst Evol Microbiol 58, 1324-1331.

Williams, S. T., Goodfellow, M., Alderson, G., Wellington, E. M. H., Sneath, P. H. A. \& Sackin, M. J. (1983). Numerical classification of Streptomyces and related genera. J Gen Microbiol 129, 1743-1813.

Xiao, J., Wang, Y., Luo, Y. X., Xie, S. J., Ruan, J. S. \& Xu, J. (2009). Streptomyces avicenniae sp. nov., a novel actinomycete isolated from the rhizosphere of the mangrove plant Avicennia mariana. Int J Syst Evol Microbiol 59, 2624-2628.

Xu, J., Wang, Y., Xu, J., Xie, S. J., Xiao, J. \& Ruan, J. S. (2009). Streptomyces xiamenisis sp. nov., isolated from mangrove sediment. Int J Syst Evol Microbiol 59, 472-476. 